\title{
INTERGOVERNMENTAL COMPETITION, VOICE AND EXIT OPTIONS AND THE DESIGN OF FISCAL STRUCTURE*
}

\author{
Michael L. Marlow**
}

\begin{abstract}
Taxpayers may reveal their assessment of policy through exercise of available voice and exit options within the fiscal constitution. The voice option is utilized when taxpayers remain within political boundaries and attempt to communicate their assessments regarding the institutional status quo to policymakers. Exercise of the exit option occurs when taxpayers signal discontent with the status quo by purchasing from another government supplier. This paper discusses and contrasts the conventional and constitutional economics views toward fiscal design and argues that a major difference exists regarding the issue of who should be awarded primary responsibility in the policy process: taxpayers or policymakers? Because voice and exit options determine the relative leverage of taxpayers and policymakers in the policy process, it is argued that the design of voice and exit options in the fiscal constitution exerts a predictable influence on policy. The paper concludes that one's view toward the design of voice and exit options is affected by one's perception of the appropriate size of government. Competitive fiscal structures tend to be advocated by those who believe that government tends to overexpand and monopolistic structures tend to be advocated by those who believe that government tends to be too small.
\end{abstract}

\section{Introduction}

The design of fiscal structure is one of the most important issues in government supply. Two elements characterize fiscal structure: the initial intergovernmental arrangement and the mechanisms, if any, that may trigger changes in that arrangement over time. Fiscal structures may be designed with little or much choice in government supply. Government monopoly eliminates choice for taxpayers while intergovernmental competition allows a degree of choice in supply for taxpayers. Taxpayers may reveal their assessment of government policy through exercise of "voice" and "exit" options (Hirschman 1970). The voice option is exercised when taxpayers remain within political boundaries and attempt to communicate their assessments regarding the status quo to policymakers. Exercise of the exit option occurs when taxpayers

\footnotetext{
*I wish to thank two anonymous referees and the editors for helpful comments.

**Professor of Economics, California Polytechnic State University, San Luis Obispo, CA 93407.
} 
signal discontent with the status quo by purchasing from another government supplier.

The conventional literature on fiscal structure is interested in designing efficient intergovernmental arrangements. Spending and taxing powers are divided among governments in the pursuit of allocative efficiency and various equity goals. As discussed by various scholars (Brennan and Buchanan 1980; Wiseman 1990), this literature is more interested in prescribing policy outcomes than analyzing the process by which individual taxpayers establish contracts with policymakers. Limited choice in government supply is often part of the fiscal design that promotes various policy outcomes (e.g., maximizing allocative efficiency). By limiting the ability of taxpayers to signal discontent through exercise of the exit option, the conventional view towards fiscal arrangements recommends that taxpayers be allowed only the voice option as the tool for producing an efficient social contract and public sector. However, in addition to providing policies that are directly demanded by taxpayers, removal of exit options allows policymakers to provide policies that are not directly demanded by taxpayers.

Proponents of the constitutional economics view of fiscal constitutions award greater leverage to individual taxpayers in the public policy process. In addition to voice options, greater choice through intergovernmental competition enables taxpayers to use exit options to influence policy. The threat of exit also enhances the ability of taxpayers to effectively exercise voice options in the public policy process.

This paper discusses and contrasts the conventional and constitutional economics approaches toward designing efficient fiscal arrangements within a simple model of the policy process. A major difference is their view regarding who should be given primary leverage in the policy process: taxpayers or policymakers? It is argued that the design of voice and exit options in the fiscal constitution exerts a predictable influence on policy outcomes. Design of voice and exit options determines the relative leverage of policymakers and taxpayers in the policy process and, over time, the abilities of taxpayers to change policies. As an example of a program designed as a monopoly of the federal government, the paper discusses the U.S. Social Security program. The paper concludes that policy prescriptions regarding the design of voice and exit options in fiscal structures are strongly affected by one's normative perception of the appropriate size of government. 


\section{Simple Model of the Public Policy Process}

A simple model of the public policy process in a representative democracy is ${ }^{1}$

$$
\text { taxpayer } \rightarrow \text { policymaker } \rightarrow \text { policy. }
$$

Taxpayers signal preferences to policymakers who, in turn, enact policy. This ideal setting avoids many complexities that inform the design of a fiscal constitution. The following are perennial topics in policy analysis. What motivates policymakers? For example, if one assumes that policymakers are self-interested, then the various constraints on policymakers influence their ability to pursue their self-interests at the expense of taxpayers. How well do taxpayers reveal their preferences to policymakers? Even if policymakers are not self-interested, inabilities of taxpayers to articulate preferences to policymakers may create differences between actual and desired policies. Moreover, even if taxpayers could perfectly articulate preferences, policymakers may not have the technical expertise to provide desired policy outcomes.

This paper studies the general issue of how the design of voice and exit options in the fiscal constitution affects the public policy process. That is, how do different institutional settings influence the mix of power between taxpayers and policymakers in the policy process? For example, does elimination of the exit option influence the outcome of the interaction between taxpayers and policymakers? Does elimination of the exit option influence the abilities of taxpayers to successfully pursue their preferences in the policy process? We consider two models of the policy process: conventional and constitutional economics models.

\section{Conventional View of Efficient Fiscal Structures}

An underlying theme of the conventional view is that voluntary interactions of private citizens within private markets fail to allocate resources efficiently. Public production is often justified on the assumption that private markets fail to optimally provide goods with properties of joint consumption and free-rider problems. Based on various efficiency criteria, the different public policies are allocated to specific

1 Assume citizens and taxpayers are identical and that organized pressure groups do not exist. 
levels of government (Oates 1972). Redistributive and stabilization activities are generally believed to be the province of the central government (Musgrave and Musgrave 1989). Monopoly provision of redistribution policies by central governments is often based on arguments that intergovernmental competition results in underproduction (Musgrave 1959 and Oates 1972). Public goods and services that are mainly local in nature are allocated to noncentral governments.

An implication of this view is that public markets improve the allocation of various resources and that taxpayers and policymakers should determine where resources are better allocated through the policy process. Within our simple model of the policy process, taxpayer $\rightarrow$ policymaker $\rightarrow$ policy, policymakers are assumed to be passive agents of the desires of taxpayers for a better allocation of resources. But it is important to realize that there are two different roles for policymakers in the policy process. One, taxpayers recognize that certain goods are characterized by nonrival consumption, nonexclusion and free rider problems and that they need to be provided by the public sector. This communication may be signalled through exercise of the voice option of Hirschman's (1970) model and may be accomplished, for example, by taxpayers utilizing voting rights and writing letters to policymakers. In this case, policymakers are the passive agents of the articulated demands of taxpayers for specific public policies.

Two, policymakers may believe that taxpayers do not adequately understand the extent to which private markets fail to produce certain goods. ${ }^{2}$ Policymakers may justify providing policies that are not directly demanded by taxpayers. Information on the appropriateness of government policy is viewed, in the case of taxpayers, as an asymmetric resource in relatively short supply. Cases where taxpayers are observed attempting to avoid policies represent some of these justified policies that are not directly appreciated by taxpayers. To the extent that taxpayers lack sufficient information about market failure, taxpayers will not be able to adequately communicate their policy preferences to policymakers. This justification for government policy is awarded much discussion in conventional analysis of optimal fiscal structure and usually considers mobility of taxpayers as a problem that government

2 See Littlechild and Wiseman (1986) for a discussion of three alternative frameworks (market failure, paternalist and libertarian) for the political economy of forcing taxpayers to accept government programs. 
monopoly overcomes. ${ }^{3}$ Pauly (1973) argues that redistribution policies of noncentral governments become self-defeating as long as citizens are mobile since, when one noncentral government raises its redistribution from the rich to the poor, the poor enter the jurisdiction as the rich leave. Because mobility thwarts the goals of redistributive policies, monopolistic provision is viewed as an appropriate device that restricts the adverse effects of mobility by taxpayers. Musgrave and Musgrave (1989: 459) argue:

It follows that if policies aimed at adjusting the distribution of income among people are to be effective, they must be conducted primarily at the central or national level. By the same token, decentralization reduces the capacity to undertake redistributional policies. Implications for such policies are therefore a strategic factor in the centralization-versus-decentralization issue.

Revenue-sharing and intergovernmental grants are also devices which restrict abilities of taxpayers to thwart the goals of policymakers. Both programs have the central government collecting taxes in excess of its spending and sharing the residual with noncentral governments. These programs are often proposed in cases of externalities (Ibid.). On a global level, Musgrave and Musgrave (1989: 455) argue that increasing internationalization of markets calls for international centralization of macroeconomic policies. Another rationale for monopolization is that larger government units exploit scale economies which serve to lower production costs.

The recent proposal in Rivlin (1991) for the reform of the fiscal constitution demonstrates the conventional view. "Uniform shared taxes" are argued to be a solution to many problems (e.g., low savings rate and inadequate government production) in our economy. A program of "uniform shared taxes" is argued to correct two problems: 1) states are unable to raise sufficient taxes because of interstate government competition and 2) states have unequal resources.

The basic idea is that states, with or without the help of the federal government, share the proceeds of a common tax on a formula basis ... The group of states agreeing to share the tax could include all 50 or could be a smaller regional grouping . . . For example, the federal government

3 However, Buchanan's (1950) fiscal residuum theory demonstrates that even with identical redistribution programs, migration would still exist on the basis of income differentials across jurisdictions. 
could enact a 5 percent value-added tax, which would raise about $\$ 100$ billion a year, and distribute it directly to the states . . . Ideally, the formula should be simple and should redistribute resources to some extent toward the poorer states (Rivlin 1991: 12).

This argument implies that changing the fiscal constitution enhances the abilities of policymakers to promote the public interest. Exit options are viewed as problems that a revised fiscal constitution should eliminate by removing interstate tax-differentials. It is important to note that the appropriate impetus for changing the fiscal constitution is argued to be from policymakers, not taxpayers. That is, that taxpayers are responsive to interstate tax differentials is assumed to not reflect an appropriate impetus for changing the fiscal constitution in the direction of lowering the tax rates of high tax states. Because of better information on the appropriateness of policy, policymakers should be able to redesign the fiscal constitution in ways that lessen the abilities of taxpayers to flee additional policies. An implication of the conventional view is that government tends to be too small when numerous exit options are a characteristic of the fiscal constitution.

Another implication of the conventional view is that the interests of taxpayers are not always served by choice in government supply. Rivlin (1991: 9) argues:

... spending programs in which national uniformity is important to effective functioning belong on the federal docket. Air traffic control is one of these. So is social insurance. No one would want 50 different social security systems, each with its own rules for payment and eligibility.

This view implies that policymakers make wise choices when designing programs such as Social Security and that fiscal constitutions. should eliminate the abilities of taxpayers to utilize the exit option to thwart the provision of those programs. The implied logic is that elimination of choice in government supply eliminates the abilities of taxpayers to choose unwise programs and that, by awarding policymakers greater leverage in the policy process, social welfare is increased. The knowledge that allows policymakers to supply wise programs is either a direct result of the communications of taxpayers to policymakers (through the voice option) or through the abilities of policymakers to determine and provide those policies that taxpayers do not understand that they need (and therefore would not be communicated through the voice option).

In sum, the conventional analysis of efficiency in fiscal structure prescribes government monopolization as an appropriate correction for 
problems inherent in a world of taxpayer mobility and asymmetric information between taxpayers and policymakers. Removal of exit possibilities controls the abilities of citizens to thwart the beneficent aims of policymakers. Removal of exit options is not considered a problem for taxpayers because taxpayer-to-policymaker communication through exercise of the voice option is relatively perfect and any additional, and appropriate, policy that is not demanded by taxpayers will be provided by far-sighted policymakers. In order for the second policy category to be delivered to taxpayers, policymakers must remove or reduce exit options through restricting intergovernmental competition.

\section{Constitutional Economics View of Efficient Fiscal Structure}

A counter view of the public policy process, taxpayer $\rightarrow$ policymaker $\rightarrow$ policy, is that it is difficult for taxpayers to not only convey useful communication to policymakers, but that self-interested policymakers may be inclined to further interests that differ from those of taxpayers. The models of logrolling, fiscal illusion, Leviathan, agenda control, rent-seeking and monopoly bureaus cast some doubt on the ability of taxpayers to communicate preferences through exercise of the voice option and receive policy which serves their best interests. This view of the policy process suggests the need to design fiscal constitutions that protect taxpayers from receiving and paying for policies which they do not desire. Because the voice option is viewed as an incomplete means of communicating the desires of taxpayers to policymakers, an important issue concerns how the design of the exit option influences the public policy process. A fundamental difference in analysis between the conventional and constitutional economics views is that the latter is more interested in studying the process by which individual taxpayers contract with policymakers rather than in prescribing final outcomes of policies.

As Hirschman (1970) argues, exercise of the exit option is often a "last resort" in that, either because of loyalty to current suppliers or because of transactions costs, it is applied when customers believe they can not effectively communicate (through voice options) strong objections about the status quo. Seldon (1990: 106) argues that, in general, the voice option is not a constraint on suppliers when the ability 
to exercise the exit option is weak or nonexistent. ${ }^{4}$ In the case of government monopoly, lack of exit possibilities imposes a different constraint on the taxpayer-policymaker relationship than when exit possibilities pose a serious threat to policymakers that deliver policies contrary to the interests of taxpayers. The constitutional economics model does not assume that policymakers are benevolent or the passive agents of taxpayers and, even if they were, policymakers are not assumed to have any additional information on the appropriateness of policy outcomes beyond that of the individual taxpayer. Removal of exit options increases the leverage of policymakers in the taxpayerpolicymaker relationship and therefore enhances the abilities of policymakers to pursue their own interests. This model of the policy process recognizes the possibility that governments "fail" and that policymakers may use fiscal structure, and monopoly power, to their advantage. If the ability of the voice option to produce appropriate policies is partially determined by the abilities of taxpayers to flee policies which they do not desire, then removal of exit possibilities lowers the effectiveness of voice options and further reduces the leverage of taxpayers in the policy process.

Wiseman (1990: 114) argues that analysis of voice and exit dimensions of a fiscal constitution is a means of appraising the efficiency of social arrangements, or the "responsiveness to the (subjective) value-systems of the individual members of a society ..." Few voice and exit options indicate a coercive fiscal constitution while many voice and exit options indicate an efficient social contract. This definition of an efficient social arrangement emphasizes the importance of the individual taxpayer and that, no matter what ex post policy outcome may emerge from a particular fiscal constitution, structures which coerce individual taxpayers are not efficient. An underlying theme of this view of the policy process is that fiscal constitutions should protect taxpayers from policymakers. In contrast, the above-discussed proposal for "uniform shared taxes" appears to rely on a methodology which protects policymakers from taxpayers and emphasizes policy outcomes within "the ends justify

4 An interesting implication of this argument is that the ability of taxpayers to use the exit option may affect the exercise of the voice option by taxpayers. For example, one hypothesis may be that relatively monopolistic political jurisdictions experience relatively low voter turn-out rates. 
the means" rationale for designing fiscal constitutions which limit the choices of taxpayers.

Brennan and Buchanan (1980) argue that exit options enhance the abilities of taxpayers to control the self-interests of policymakers. ${ }^{5}$ With free trade and costless migration, explicit fiscal constraints on policymakers are argued to be unnecessary in a Tiebout (1956) world of competing governments. That is, existence of many exit options protects taxpayers from receiving policies which they do not desire. Policymakers who deliver policies that taxpayers do not desire either must start providing what taxpayers want or suffer an exodus of their taxpayers to competing governments. However, the availability of exit options only partially constrains the abilities of policymakers to pursue their self-interests when there exist mobility costs, large central governments and imperfect information. In this case, constitutional limits on government are argued to be effective alternative controls on policymakers. Since collusion potential falls with competition between suppliers, intergovernmental competition is viewed as a desirable constraint on policymakers.

From the constitutional economics model of the policy process, the inclusion of intergovernmental grants and revenue-sharing into fiscal constitutions is also questioned. Consistent with Tullock's (1969) rentseeking hypothesis, governments may be argued to seek collusive institutional arrangements that weaken competitive pressures, such as a system of grants where noncentral governments spend funds that they themselves do not collect. As grants remove competitive pressures between noncentral governments, grants also enhance the monopoly power of the central government in its tax collection effort. McKenzie and Staff (1978) and Lee (1985) view these activities as legal tax cartel arrangements. That conventional analysis predicts that benevolent governments do not exploit such arrangements is evident from the above discussion of Rivlin's (1991) proposal for "uniform shared taxes." A prediction from the constitutional economics model is that, not only do governments exploit such arrangements, governments actively create such arrangements since they lower the abilities of taxpayers to utilize

5 It may be more informative to say that it protects taxpayers from receiving policies which they do not desire. Whether or not some of these undesired policies are a product of public-spirited policymakers or a product of self-interested policymaking is a complex issue that will not be considered here. 
voice and exit options to prevent unpopular policies which policymakers wish to deliver to them.

\section{Central Government Monopoly: The Case of Social Security}

From a constitutional economics viewpoint, the central government's monopoly in Social Security is predicted to eliminate intergovernmental competition and lead it to be administered at relatively high resource costs and low quality. Monopolization of Social Security also lowers the financial incentive of taxpayers to vote-with-their-feet on the basis of differential intergovernmental tax and spending policies. That is, monopolization of Social Security influences intergovernmental competition in two ways (Joulfaian and Marlow 1991). One way is to remove possibilities for competition within the area of Social Security. Here taxpayers can not gain, within a given country, by moving from one government to another since all locations offer identical Social Security tax burdens. Monopolization of this program removes the exit possibilities for this policy. While noncentral governments, and private firms, also provide pensions, they are not competitors to the central government monopoly since their provision is over-and-above that of Social Security. The recent growth of private pensions, however, may indicate the degree to which the Social Security system is viewed as inadequate by taxpayers. ${ }^{6}$ If subjected to competing government, or private, providers, it is predicted that the current Social Security program would experience substantial exodus by taxpayers, or would become more efficient and attractive to participants. Without exit possibilities, taxpayers must rely on their exercise of the voice option and the wisdom of policymakers to improve policy.

The other way that monopolization of Social Security influences intergovernmental competition is through its influence on the competitiveness of aggregate government. Monopolization of the Social Security program not only eliminates intergovernmental competition within the Social Security program, but it also reduces intergovernmental

6 For example, over 1970-1989, private pensions' share of total private financial assets has grown from $2 \%$ to $4 \%$. Data obtained from table 794 in U.S. Bureau of the Census (1990). 
competition between all programs of central and noncentral governments. That is, monopolization of Social Security removes from competition a subset of total government activity. For example, the ratio of Social Security taxes-to-total government (federal + state + local) taxes has risen from .03 to .24 over 1950-1989 and suggests that Social Security policy has led to greater monopolization of the tax policies of all governments. ${ }^{7}$ The federal government monopoly in Social Security also commands mandatory participation of virtually every worker. The percentage of the civilian workforce covered under Social Security has grown substantially over time: $58.7 \%$ (1950), $79.4 \%$ (1960), $83.7 \%$ (1970), $90.2 \%$ (1980), 93.8\% (1988). ${ }^{8}$ The 1983 Amendments to the Social Security Act granted coverage to virtually every new-hire in the workforce (Musgrave and Musgrave 1989: 195).

One specific example of the growing monopolization of Social Security is in the case of state and local government employees. For example, before 1951, state and local government employees were ineligible for participation in Social Security (U.S. Bureau of the Census 1987). Several important changes since 1951 have affected the ability of state and local governments to provide pensions to their employees. On January 1, 1983, state and local governments were no longer able to withdraw from the Federal program and effective April 1, 1986, the health portion of Social Security became mandatory for all new state and local government employees.

Crain and Marlow (1990) argue that Social Security exerts a positive influence on the size of the federal government. When Congress passed the Social Security Act of 1935, it did not require the Social Security system to be fully-funded in the sense that it is not required to save, or put aside, funds for payment of future obligations. Rather, its pay-asyou-go funding constraint only requires it to meet current operating expenses and benefits. Current benefits of retirees are financed by the current Social Security tax contributions of workers. While taxes in excess of current obligations may be invested in its trust funds, policymakers have the ability to use "excess" taxes to fund non-Social Security programs. This is possible, in part, because Social Security tax revenues do not flow into its trust funds but, instead, in exchange for

7 Data obtained from U.S. Bureau of the Census (1990).

8 Data for 1950, 1960 and 1970 obtained from Kotlikoff and Smith (1983) and for 1980 and 1988 from U.S. Bureau of the Census (1990). 
IOUs to the trust funds, they flow like any other tax to the U.S. Treasury. To the extent that Social Security taxes are viewed as saved through the policy process, taxpayers may exhibit fiscal illusion whereby taxpayers underestimate the discounted value of future tax burdens. ${ }^{9}$ Crain and Marlow (1990) present evidence that policymakers use Social Security taxes to fund non-Social Security spending that lead to overall federal government expansion.

It is useful to analyze the design of voice and exit options in the institutional structure of the Social Security program. While conventional analysis of the policy process assumes that exercise of the voice option produces useful communication from taxpayers to policymakers, this may not be true in the case of Social Security. If, for example, taxpayers do not fully understand the unique financing characteristics of the program, then information they communicate to policymakers will be imperfect. With weak voice characteristics and without exit possibilities, implementation of appropriate policy requires that policymakers somehow provide it. Under the conventional model of the policy process, it is assumed that policymakers are up to the task, while the constitutional economics model suggests that appropriate policy may not be forthcoming.

It is also useful to analyze the conventional proposition, as suggested in Rivlin (1991: 9), that "No one would want 50 different social security programs, each with its own rules for payment and eligibility." This proposition implies that the availability of choice in Social Security supply would somehow produce a worse program than when it is designed as a monopoly program of the federal government. Several problems with this proposition are evident. With elimination of exit options, what recourses are left for dissatisfied taxpayers in a world of imperfect voice options and self-interested policymakers? Another issue is whether or not elimination of the exit option reduces the probability that appropriate changes in policies are possible over time. If yes, removal of exit options violates the "responsiveness to the value systems of individuals" component in Wiseman's (1990) definition of efficiency in social arrangements. Another issue is: Why is Social Security different from other financial instruments that are offered by private

9 Barro (1974) discusses an alternative hypothesis, Ricardian Equivalence, which suggests that taxpayers can not be fooled into underestimating the true tax burdens associated with "complex" tax structures like Social Security. 
financial firms? For example, would it be preferable to have one monopoly bank so as to eliminate differences (and therefore taxpayer-choice as well) in banks (e.g., banking hours, asset-and liability- managements, number of branches, interest rate differentials, etc.)?

The issue of whether or not Social Security should be designed as a welfare or income transfer system may dictate whether it is designed to operate on a fully-funded or pay-as-you-go basis and whether its design allows exit options. For example, exit options are inconsistent with a pay-as-you-go system, since that system is designed to redistribute income. ${ }^{10}$ With exit options, retirees would tend to migrate to areas where Social Security tax revenues per retiree are highest and therefore undermine the ability of policymakers to redistribute income. In other words, policymakers who wish to redistribute income through the Social Security program would prefer that the program operate on a pay-as-you-go basis and recommend that its structure eliminate exit options. On the other hand, if policymakers wished to make the Social Security program a pension fund whereby government invested the savings of taxpayers in a fund that would be utilized at the time of their retirement, the program would be designed with a fully-funded operating constraint. Fifty different state systems would be viable under a contractually-grounded, fully-funded method of finance that vests funds with the contributors, but it would be inconsistent with maintenance of pay-as-you-go systems that allowed exit options for contributors and beneficiaries. ${ }^{11}$ Without the goal of redistributing income, the availability of exit options would not tend to undermine the viability of fifty different and fully-funded state systems, but, rather, tend to strengthen the financial soundness of programs since they would now be subject to intergovernmental competition.

\section{Conclusion}

One recommendation that follows from the conventional model of the policy process is that constitutions should be designed with controls

10 See Browning and Browning (1987) for a discussion of these issues.

11 If the program is not designed to redistribute income, then the importance of having it publicly provided also diminishes since, like private savings accounts, they could be provided by the private sector. In this case, some policymakers may argue that public provision remains necessary because, without a public program, some subset of taxpayers would not save for their retirement. Of course, critics of this view may argue that the current Social Security system does not do a better job of saving for taxpayers. While these issues are interesting, they are not the focus of this paper. 
on the abilities of taxpayers to flee benevolent government policies. Analysis using the constitutional economics model of the policy process raises the possibility that policymakers are not benevolent and that the interests of taxpayers are furthered by choice in government supply. Widened choice in supply is argued to enhance the communication characteristics of the voice and exit options within the policy process and lead to policies that better reflect the desires of taxpayers.

Some fiscal constitutions, such as in the case of Social Security, are designed to eliminate choice in government supply. Analysis from the conventional viewpoint emphasizes the importance of policy outcomes and therefore recommends that fiscal constitutions be designed so as to discourage the ability of taxpayers to refuse policies that policymakers believe improve social welfare. Analysis within the constitutional economics viewpoint emphasizes the importance of designing fiscal constitutions which do not coerce individual taxpayers and therefore recommends that unlimited exit options be a characteristic of the constitution.

That more centralized governments tend to be larger governments may explain the underlying motivation for the dichotomy in policy prescriptions regarding the design of the exit option. ${ }^{12}$ Elimination of exit options may tend to be advocated by those who believe that the public sector tends to be too small. Monopolization through elimination of exit options allows policymakers to provide policies that mobile taxpayers would tend to flee. Monopolization under this normative assessment of government size appears to be a natural policy prescription since, by lowering the ability of taxpayers to utilize voice and exit options within the policy process, monopolistic structures expand the abilities of policymakers to provide policies.

Relatively competitive fiscal structures may tend to be advocated by those who believe that government tends to overexpand and therefore exit possibilities are considered to be desirable elements of the constitution since they enhance the abilities of taxpayers to reject policies that they do not want. Given the differences in perceptions of the appropriate size of government, it is not surprising that such diverse views exist on the design of efficient fiscal constitutions. The alternative models of the policy process indicate that the primary difference rests on who is believed to recognize appropriate policy: taxpayers or policymakers?

12 See Marlow (1988) and Joulfaian and Marlow (1991) for a discussion of the empirical evidence on the centralization-government size relationship. 
Proponents of the conventional model of the policy process prescribe that fiscal constitutions be designed with primary leverage awarded to policymakers while proponents of the constitutional economics model recommend that individual taxpayers be awarded primary leverage in the policy process.

\section{REFERENCES}

Barro, R.J. (1974) “Are Government Bonds Net Wealth?' Journal of Political Economy 82: $1095-1117$.

Brennan, G. and J.M. Buchanan (1980) The Power to Tax: Analytical Foundations of a Fiscal Constitution. Cambridge: Cambridge University Press.

Browning, E.K. and J.M. Browning (1987) Public Finance and the Price System. 3rd ed. New York: Macmillan Publishing Company.

Buchanan, J.M. (1950) "Federalism and Fiscal Equity." American Economic Review 40: 583-599.

Crain, W.M. and M.L. Marlow (1990) "The Relation Between Social Security and the Federal Budget." In: C. Weaver (ed) Social Security's Looming Surplus. Washington, DC: American Enterprise Institute.

Hirschman, A.O. (1970) Exit, Voice and Loyalty. Cambridge: Harvard University Press. Joulfaian, D. and M.L. Marlow (1991) "Centralization and Government Competition." Applied Economics 23: 1603-1612.

Kotlikoff, L.J. and D.E. Smith (1983) Pensions in the American Economy. National Bureau of Economic Research monograph.

Lee, D.R. (1985) "Reverse Revenue-Sharing: A Modest Proposal." Public Choice 45: 279-289.

Littlechild, S.C. and J. Wiseman (1986) "The Political Economy of Restriction of Choice." Public Choice 51: 161-172.

Marlow, M.L. (1988) "Fiscal Decentralization and Government Size." Public Choice 56: 259-269.

McKenzie, R.B. and R.J. Staff (1978) "Revenue Sharing and Monopoly Government." Public Choice 33: 93-97.

Musgrave, R.A. (1959) The Theory of Public Finance. New York: McGraw Hill.

Musgrave, R.A. and P.B. Musgrave (1989) Public Finance in Theory and Practice. 5th ed. New York: McGraw Hill, Inc.

Oates, W. E. (1972) Fiscal Federalism. New York: Harcourt Brace Jovanovich.

Pauly, M.V. (1973) "Income Redistribution as a Local Public Good." Journal of Public Economics 2: 35-58.

Rivlin, A.M. (1991) "Distinguished Lecture on Economics in Government: Strengthening the Economy by Rethinking the Role of the Federal and State Governments." Journal of Economic Perspectives 5: 3-14.

Tiebout, C.M. (1956) "A Pure Theory of Local Government Expenditures." Journal of Political Economy 64: 416-424.

Tullock, G. (1967) "The Welfare Costs of Tariffs, Monopolies, and Theft." Economic Inquiry 5: 224-232. 
U.S. Bureau of the Census (various years) Census of Governments, Employee-Retirement Systems of State and Local Governments.

U.S. Bureau of the Census (1990) Statistical Abstract of the United States: 1990. Washington, DC.

Wiseman, J. (1990) "Principles of Political Economy: An Outline Proposal, Illustrated with Application to Fiscal Federalism." Constitutional Political Economy 1: 101-124. 